\title{
Occurrence of Enterobacteriaceae in Raw Meat and in Human Samples from Egyptian Retail Sellers
}

\author{
Mayada Gwida, ${ }^{1}$ Helmut Hotzel, ${ }^{2}$ Lutz Geue, ${ }^{3}$ and Herbert Tomaso ${ }^{2}$ \\ ${ }^{1}$ Department of Hygiene and Zoonoses, Faculty of Veterinary Medicine, Mansoura University, Mansoura 35516, Egypt \\ ${ }^{2}$ Friedrich-Loeffler-Institut, Institute of Bacterial Infections and Zoonoses, 07743 Jena, Germany \\ ${ }^{3}$ Friedrich-Loeffler-Institut, Institute of Molecular Pathogenesis, 07743 Jena, Germany
}

Correspondence should be addressed to Mayada Gwida; mayada.gwida@gmail.com

Received 26 June 2014; Revised 9 October 2014; Accepted 10 October 2014; Published 11 November 2014

Academic Editor: Bianca Castiglioni

Copyright (C) 2014 Mayada Gwida et al. This is an open access article distributed under the Creative Commons Attribution License, which permits unrestricted use, distribution, and reproduction in any medium, provided the original work is properly cited.

\begin{abstract}
The present study was performed to assess the presence of Enterobacteriaceae in raw meat and handlers in Egypt using cultivation and matrix-assisted laser desorption ionization time-of-flight mass spectrometry (MALDI-TOF MS). A total of 100 raw meat samples (chicken and beef meat, 50 each) were randomly purchased from butchers and local meat retailers located at Mansoura city, Egypt. Fifty human samples were collected from meat handlers (hand swabs and stool specimens, 25 each). 228 bacterial isolates were recovered from these samples. Unidentified isolates were characterized by partial 16S rRNA gene sequencing. Escherichia coli isolates were further typed using a DNA microarray system. Proteus spp. (60.0\%) were found to be the most abundant followed by Escherichia coli (38.7\%), Klebsiella spp. (17.3\%), and Citrobacter spp. (13.3\%). The presence of different Enterobacteriaceae in locally produced retail raw meat demonstrates the risk of infection of people through consumption of raw or undercooked meat and the risk for cross-contamination of other food products. Harmonized and concerted actions from veterinary and public health authorities are needed to reduce the risk of infection.
\end{abstract}

\section{Introduction}

Most of the pathogens that play a role in foodborne diseases are of animal origin [1]. Foodborne diseases pose a serious threat to the health of people in Africa and cause huge economic losses [2]. Up to one-third of the population in developing countries is affected by foodborne diseases each year. It is assumed that foodborne and waterborne diarrheal diseases kill more than 2.2 million people each year [3]. A major problem in food hygiene is the fecal contamination of beef and chicken meat with Enterobacteriaceae such as Salmonella spp., Escherichia (E.) coli, Proteus (P.), and Klebsiella (K.) species $[4,5]$. To minimize the prevalence of foodborne diseases and to reduce the microbial contamination of food, effective monitoring of the occurrence and reliable identification of zoonotic bacterial pathogens in food is essential. Currently, routine detection of foodborne pathogens relies on cultivation and biochemical identification [6]. These methods are laborious and time-consuming, and may lead to false identifications [7]. In recent years, MALDI-TOF MS has been implemented in microbiological routine laboratories for broad-spectrum identification of bacteria [8-11]. The present study was performed to assess the presence of Enterobacteriaceae in raw meat and handlers in Egypt using cultivation of bacteria and MALDI-TOF MS. When MALDI-TOF MS lead to doubtful results, partial sequencing of 16S rRNA genes was used to verify the identification. Furthermore, E. coli isolates were characterized by microarray analysis.

\section{Material and Methods}

2.1. Sample Collection. The study was conducted between October 2012 and May 2013. A total of 100 fresh raw meat samples (chicken and beef meat, 50 each) were randomly purchased from butchers and local meat retailers located in Mansoura city, Egypt. In addition, 50 human samples (hand 
swabs and stool specimens from meat handlers, 25 each) were collected. The samples were placed on ice and transported immediately to the Hygiene and Zoonoses laboratory, Faculty of Veterinary Medicine, Mansoura University, Egypt. An informed consent was obtained from all persons involved in this study.

2.2. Sample Preparation. Twenty-five grams of each raw beef or chicken meat was transferred to a blender bag and homogenized with $225 \mathrm{~mL}$ of $0.1 \%$ buffered peptone water (BPW; Oxoid, Wesel, Germany). Pre-enrichment was done for $24 \mathrm{~h}$ at $37^{\circ} \mathrm{C}$. A loop full of the enriched broth was streaked on MacConkey agar plates (Oxoid) and Eosin Methylene Blue Lactose plates (Oxoid) and incubated at $37^{\circ} \mathrm{C}$ for $24 \mathrm{~h}$. For human samples, hand swabs and stool specimens were directly inserted into sterile tubes containing $10 \mathrm{~mL}$ BPW under aseptic conditions and incubated at $37^{\circ} \mathrm{C}$ for $24 \mathrm{~h}$. Then, the samples were cultivated as described previously.

2.3. Bacterial Identification. Colonies were picked and streaked onto nutrient agar plates, incubated at $37^{\circ} \mathrm{C}$ for $18-24 \mathrm{~h}$ and then stored at $-20^{\circ} \mathrm{C}$ as glycerol cultures until shipping to the Friedrich-Loeffler-Institut, Institute of Bacterial Infections and Zoonoses, Jena, Germany. In Germany, the bacterial isolates were identified using MALDITOF MS as described by Karger et al. [12]. Briefly, bacteria were cultivated on Columbia sheep blood agar at $37^{\circ} \mathrm{C}$ for $24 \mathrm{~h}$. Single colonies were picked, suspended in $300 \mu \mathrm{L}$ of water, and precipitated by addition of $900 \mu \mathrm{L}$ of ethanol $\mathrm{p}$. a. (Carl Roth $\mathrm{GmbH}$, Karlsruhe, Germany). Samples were centrifuged at $10,000 \mathrm{~g}$ for two minutes. The supernatant was carefully removed and the sediment was resuspended in $50 \mu \mathrm{L}$ of $70 \%(\mathrm{v} / \mathrm{v})$ formic acid (Sigma-Aldrich Chemie $\mathrm{GmbH}$, Taufkirchen, Germany). After mixing with $50 \mu \mathrm{L}$ acetonitrile (Carl Roth $\mathrm{GmbH}$ ), the suspension was centrifuged as described above and the supernatant was transferred into a fresh tube. One $\mu \mathrm{L}$ of the supernatant was spotted two times onto a MALDI target plate (polished steel MTP 384 plate, Bruker Daltonik GmbH, Bremen, Germany) and allowed to dry at room temperature. Finally, the dried spots were overlaid with one $\mu \mathrm{L}$ of matrix, which was a saturated solution of $\alpha$-cyano-4-hydroxycinnamic acid (Sigma-Aldrich Chemie $\mathrm{GmbH}$ ) in 50\% acetonitrile and 2.5\% trifluoroacetic acid (Sigma-Aldrich Chemie $\mathrm{GmbH}$ ). As soon as the samples were air-dried-measurement was started within $10 \mathrm{~min}$.

Spectra were acquired with 300 laser shots with an Ultraflex I instrument (Bruker Daltonik $\mathrm{GmbH}$ ) in the linear positive mode in the range of 2,000 to 20,000 Da. Acceleration voltage was $25 \mathrm{kV}$ and the instrument was calibrated in the range between 3,637.8 and 16,952.3 Da using the IVD Bacterial Test Standard Calibrant (BTS; Bruker Daltonik $\mathrm{GmbH}$ ). For species identification, the BioTyper database 3.0 (Bruker Daltonik GmbH) was used. An identification (ID) score $>2.30$ is regarded a highly probable species identification; scores 2.0-2.29 indicate secure genus and probable species identification; scores 1.70-1.99 allow probable genus identification and lower scores provide no reliable results
(Table 3). Unidentified bacteria and bacteria with a score $<2.0$ were identified using partial $16 \mathrm{~S}$ rRNA gene sequencing.

2.4. DNA Extraction and Partial 16S rRNA Gene Sequencing. Isolation of DNA was carried out with a High Pure PCR Template Preparation Kit (Roche Diagnostics, Mannheim, Germany) according to the manufacturer's instructions. Partial 16S rRNA genes of unidentified bacterial isolates were amplified by PCR with 16SUNI-L ( $5^{\prime}$-AGA GTT TGA TCA TGG CTC AG- ${ }^{\prime}$ ) as the forward primer and 16SUNIR ( $5^{\prime}$-GTG TGA CGG GCG GTG TGT AC-3') as the reverse primer (Jena Bioscience $\mathrm{GmbH}$, Jena, Germany) to generate approximately 1,400-bp amplicon as published by Kuhnert et al. [13]. PCR products were analyzed by agarose gel electrophoresis, ethidium bromide staining, and visualization under UV light. Bands were cut out, and DNA was purified using a Gel Extraction Kit (Qiagen, Hilden, Germany) according to the manufacturer's recommendations. Cycle sequencing of partial 16S rRNA genes was done in both directions by using forward and reverse amplification primers with a BigDye Terminator Version 1.1 Cycle Sequencing Kit (Applied Biosystems, Darmstadt, Germany) according to the recommendations of the manufacturer. Sequencing products were analyzed with an ABI Prism 3130 Genetic Analyzer (Applied Biosystems). Identification of isolates was done by a BLAST search (http:// www.ncbi.nlm.nih.gov/blast/) using $16 \mathrm{~S}$ rRNA gene sequences.

2.5. Genotype Characterization by E. coli Genotyping Microarray. Sixteen $E$. coli isolates were selected for the genotype characterization using a DNA microarray system. DNA was extracted as described above. DNA concentration was determined spectrophotometrically. Miniaturized E. coli oligonucleotide arrays in the ArrayStrip format (Alere Technologies $\mathrm{GmbH}$, Jena, Germany), E. coli Genotyping Kit (Kit for DNA-based detection of virulence genes in E. coli isolates, Cat. number 205400050) containing gene targets for the identification of virulence genes [14], antimicrobial resistance genes [15], and DNA-based serotyping [16] were used for the genetic characterization of the E. coli isolates.

For labeling and biotinylation of the genomic DNA, a sitespecific labeling approach was used as published by Monecke and Ehricht [17]. Primer elongation, hybridization, washing, and staining of array strips were described previously by Geue et al. [18]. The array strips were photographed using an Array Mate instrument (Alere Technologies $\mathrm{GmbH}$ ) and automatically analyzed. After automated spot detection, mean signal intensity (mean) and local background (lbg) were measured for each probe position and values were calculated by the formula value $=1-$ mean $/ \mathrm{lbg}$. Resulting values below 0.1 were considered negative and above 0.3 were considered positive. Values between 0.1 and 0.3 were regarded as ambiguous. Validation was performed using a collection of sequenced control strains (GeneBank Accession numbers AE005174 (E. coli EDL933 O157:H7), FM180568 (E. coli E2348/69 O127:H6), U00096 (E. coli K-12 MG1655), AP009048 (E. coli K-12 W3110), CP000247 (E. coli O6:K15:H31), CP001509 
TABLE 1: Identification of Enterobacteriaceae in meat and meat handler samples by MALDI-TOF MS.

\begin{tabular}{|c|c|c|c|c|c|c|c|c|c|c|c|c|}
\hline $\begin{array}{l}\text { Identified } \\
\text { microorganism }\end{array}$ & $\begin{array}{c}\text { Raw } \\
\text { beef } \\
\text { meat } \\
(n=50) \\
\end{array}$ & $\%$ & $\begin{array}{c}\text { Raw } \\
\text { chicken } \\
\text { meat } \\
(n=50)\end{array}$ & $\%$ & Total & $\%$ & $\begin{array}{c}\text { Stool } \\
\text { specimens } \\
(n=25)\end{array}$ & $\%$ & $\begin{array}{l}\text { Hand } \\
\text { swabs } \\
(n=25)\end{array}$ & $\%$ & Total & $\%$ \\
\hline Citrobacter spp. & 12 & 24.0 & 1 & 2.0 & 13 & 13.0 & 4 & 16.0 & 3 & 12.0 & 7 & 14.0 \\
\hline C. amalonaticus & 0 & 0 & 0 & 0 & 0 & 0 & 1 & 4.0 & 1 & 4.0 & 2 & 8.0 \\
\hline C. freundii & 5 & 10.0 & 1 & 2.0 & 6 & 6.0 & 3 & 12.0 & 1 & 4.0 & 4 & 8.0 \\
\hline C. braakii & 3 & 6.0 & 0 & 0 & 3 & 3.0 & 1 & 4.0 & 1 & 4.0 & 2 & 8.0 \\
\hline C. koseri & 3 & 6.0 & 0 & 0 & 3 & 3.0 & 0 & 0 & 0 & 0 & 0 & 0 \\
\hline C. youngae & 1 & 2.0 & 0 & 0 & 1 & 1.0 & 0 & 0 & 0 & 0 & 0 & 0 \\
\hline Enterobacter cloacae & 0 & 0 & 0 & 0 & 0 & 0 & 2 & 8.0 & 0 & 0 & 2 & 4.0 \\
\hline Escherichia coli & 27 & 54.0 & 8 & 16.0 & 35 & 35.0 & 17 & 68.0 & 6 & 24.0 & 23 & 46.0 \\
\hline Klebsiella spp. & 3 & 6.0 & 13 & 26.0 & 16 & 16.0 & 1 & 4.0 & 9 & 36.0 & 10 & 20.0 \\
\hline K. pneumoniae & 3 & 6.0 & 11 & 22.0 & 14 & 14.0 & 0 & 0 & 6 & 24.0 & 6 & 12 \\
\hline K. oxytoca & 0 & 0 & 2 & 4.0 & 2 & 2.0 & 1 & 4.0 & 3 & 12.0 & 4 & 8.0 \\
\hline Morganella morganii & 16 & 32.0 & 2 & 4.0 & 18 & 18.0 & 0 & 0 & 2 & 8.0 & 2 & 4.0 \\
\hline Proteus spp. & 29 & 58.0 & 39 & 78.0 & 68 & 68.0 & 15 & 60.0 & 7 & 28.0 & 22 & 44.0 \\
\hline P. vulgaris & 22 & 44.0 & 0 & 0 & 22 & 22.0 & 4 & 16.0 & 0 & 0 & 4 & 8.0 \\
\hline P. mirabilis & 6 & 12.0 & 39 & 78.0 & 45 & 45.0 & 11 & 44.0 & 7 & 28.0 & 18 & 36.0 \\
\hline P. penneri & 1 & 2.0 & 0 & 0 & 1 & 1.0 & 0 & 0 & 0 & 0 & 0 & 0 \\
\hline Providencia spp. & 1 & 2.0 & 1 & 2.0 & 2 & 2.0 & 0 & 0 & 0 & 0 & 0 & 0 \\
\hline Providencia stuartii & 0 & 0 & 1 & 2.0 & 1 & 1.0 & 0 & 0 & 0 & 0 & 0 & 0 \\
\hline Raoultella spp. & 5 & 10.0 & 2 & 4.0 & 7 & 7.0 & 0 & 0 & 3 & 12.0 & 3 & 6.0 \\
\hline R. planticola & 5 & 10.0 & 0 & 0 & 5 & 5.0 & 0 & 0 & 1 & 4.0 & 1 & 2.0 \\
\hline R. ornithinolytica & 0 & 0 & 2 & 4.0 & 2 & 2.0 & 0 & 0 & 2 & 8.0 & 2 & 4.0 \\
\hline Serratia liquefaciens & 1 & 2.0 & 0 & 0 & 1 & 1.0 & 0 & 0 & 0 & 0 & 0 & 0 \\
\hline $\begin{array}{l}\text { Total number of } \\
\text { isolates }\end{array}$ & 94 & & 66 & & 160 & & 39 & & 29 & & 68 & \\
\hline
\end{tabular}

(E. coli BL21), AE014075 (E. coli CFT073), and CP000946 (E. coli ATCC 8739)).

\section{Results and Discussion}

Rapid, accurate, and reliable detection and identification of bacterial foodborne pathogens are critical for food safety. The gold standard is bacterial isolation followed by microscopic and biochemical identifications, which is time-consuming and laborious [6].

In recent years, MALDI-TOF MS has been introduced in microbiological routine laboratories, because it provides results within only a few hours. The instruments are still expensive, but reagent costs are low, and identification of bacteria can be largely automated. The bacteria are identified by comparing the obtained mass spectra to those from a reference library [8]. Limitations have been observed for bacteria that require special sample preparation and some very closely related species. The following bacteria were identified only by partial 16S rRNA gene sequencing: Staphylococcus sciuri, Lysinibacillus spp., and Macrococcus caseolyticus.

The highest number of strains was isolated from raw beef, followed by raw chicken meat, seller stool specimens, and hand swabs from sellers. The high number of Proteus isolates from chicken meat $(78.0 \%)$ and beef meat $(58.0 \%)$ was remarkable. The presence of Proteus spp. in the meat samples can obviously be attributed to unhygienic food processing. Proteus spp. were isolated and identified by researchers from raw meat and its products in other studies in Egypt [19-23].

Twenty-seven bacterial isolates out of $50(54.0 \%)$ and 8 out of $50(16.0 \%)$ samples of raw beef and chicken meat, respectively, were identified as $E$. coli. In several studies, E.coli was isolated in a high percentage from raw meat and unprocessed ready-to-eat products [24-30]. Contamination may occur due to bowel rupture or use of contaminated water during evisceration and slaughtering [31, 32]. However, neither MALDI-TOF MS analyses nor 16S rRNA gene sequencing allows differentiation between Shigella spp. and E. coli. A total of 16 presumptively identified E. coli isolates were characterized for the genoserotypes, E. coli virulence associated genes, and antibiotic resistance genes using a DNA microarray. A complete DNA-based assigned serotype was determined only in five E. coli isolates. Only serotype O103:H7 could be characterized completely, because the number of $\mathrm{O}$ antigens detectable by this method is currently limited. In 10 other isolates, $\mathrm{fliC}$ genes for $\mathrm{H} 2$ (5 isolates), H49 (found twice), and H19, H31, or H38 were detected, respectively. In one isolate, neither the O-antigen nor the fliC gene could be found (Table 2). From $68.0 \%$ of the stool samples and $24.0 \%$ of the hand swabs of meat sellers, E. coli was isolated (Table 1). This high prevalence could 
TABLE 2: Phylogenetic characteristics and DNA-based serotypes of tested Escherichia coli isolates.

\begin{tabular}{|c|c|c|c|}
\hline Number & Serotype* & Virulence marker & Resistance marker \\
\hline 1 & O103:H7 & hemL, lpfA, tsh, iroN, iss & \\
\hline 2 & On.d.:H19 & blaTEM & \\
\hline 3 & O103:H7 & hemL, lpfA, tsh, iroN, iss & \\
\hline 4 & O103:H7 & $\operatorname{lpf} A$, tsh, iroN, iss & \\
\hline 5 & On.d.:H38 & $\begin{array}{c}\text { stx2 (subtype } 2 a \text { or } 2 c \text { or } 2 d) \text {, ehxA, espI, espP, } \\
\text { saa, iha, subA, iss }\end{array}$ & \\
\hline 6 & On.d.:H2 & $c b a, c d t B, c m a, c n f 1, f 17-G, l p f A$, iroN, iss & \\
\hline 7 & On.d.:H31 & $l p f A, c d t B, c n f 1, f 17-A, f 17-G$ & \\
\hline 8 & O103:H7 & hemL, lpfA, tsh, iroN, iss & tetA \\
\hline 9 & On.d.:H49 & hemL, lpfA & \\
\hline 10 & On.d.:H2 & lpfA, cba, cdtB, cma, cnfl, f17-G, iro, iss & \\
\hline 11 & O103:H7 & hemL, lpfA, tsh, iroN, iss & tetA \\
\hline 12 & On.d.:Hn.d. & $\operatorname{lpf} A$ & blaTEM \\
\hline 13 & On.d.:H49 & $\operatorname{lpfA}$ & \\
\hline 14 & On.d.:H2 & $\operatorname{lpf} A$, & \\
\hline 15 & On.d.:H2 & $\operatorname{lp} f A$ & \\
\hline 16 & On.d.:H2 & hemL, lpfA & blaMOX-CMY9, blaOXA, blaVIM \\
\hline
\end{tabular}

${ }^{*}$ n.d.: not detectable by microarray.

be attributed to inadequate sanitary conditions and poor general hygiene. Stephan et al. [33] detected E. coli verotoxin encoding genes in $3.5 \%$ of healthy employees in the meat industry. Numerous $E$. coli virulence associated markers were tested using the oligonucleotide microarrays. The stx2 gene was found in one of the 16 isolates only. The isolates were characterized as stx $2 a$ or stx $2 c$ or stx $2 d$ subtypes in accordance with the nomenclature published by Lewis [34]. The microarray does not allow more differentiated subtyping. The ehxA gene encoding the EHEC hemolysin was detected in the same isolate. The plasmid encoded virulence genes esp $P$ (encoding for a serine protease), saa (encoding for the STEC autoagglutinating adhesin), subA (encoding for a subtilase cytotoxin), and iss (increased serum resistance) were also demonstrated in the same isolate. However, intimin genes were not found. A non-LEE-encoded effector protein gene (espI) and the gene for enterobactin siderophore receptor/adhesin (iha) were also obtained (Table 2 ). In the other $E$. coli isolates, the genes for fimbria adhesion (lpfA, 14 isolates) and iss (increased serum resistance, 7 isolates) were demonstrated frequently. The gene for a glutamate-1semialdehyde aminotransferase (hemL, 5 isolates), the $t s h$ gene (encoding for a hemoglobin binding protein, 5 isolates), and the gene for an outer membrane siderophore receptor (iroN, 4 isolates) were found rarely. The $c b a$ gene (encoding for a bacteriocin, 2 isolates), the cma gene (also encoding for a colicin, 2 isolates), the $c d t B$ gene (encoding for a cytolethal distending toxin, 3 isolates), and the $c n f 1$ gene (encoding for a cytotoxic necrotizing factor type 1, 3 isolates) were amplified in some isolates. Additional genes for major fimbrial subunit proteins ( $f 17-A$ and $f 17-G$ ) were found in 3 isolates. It is noteworthy that isolates belonging to the same serotype were nearly identical regarding the virulence markers (Table 2).
Genes associated with antibiotic resistance were found rarely. Only in 5 of the $16 \mathrm{E}$. coli isolates such genes were observed. The tet $A$ (encoding for tetracycline resistance protein A) and the blaTEM (encoding for a $\beta$-lactamase class A) were detected in two isolates, respectively. Genes for three $\beta$-lactamase associated genes (blaMOX-CMY9, blaOXA, and blaVIM) were found in an On.d.:H2 E. coli isolate (Table 2).

Klebsiella spp. were isolated from 3 samples of raw beef (6.0\%) and 13 samples (26.0\%) of raw chicken meat. A high incidence of Klebsiella spp. from raw meat products was reported previously by Gill [22] and Gibbons et al. [23]. The majority of the Egyptian population purchase raw meat from small local butchers. Meat is usually offered for sale in openair shops without cooling resulting in potentially heavily contaminated products. Our data confirmed that the locally produced and sold meat is of poor bacteriological quality and poses a high risk for consumer health.

Klebsiella oxytoca and Raoultella ornithinolytica isolates are known to have very similar spectra in MALDI-TOF MS and can potentially be confused with each other. However, this was not further investigated in this study. Other members of the family Enterobacteriaceae causing gastroenteritis like Proteus spp., Citrobacter spp., Klebsiella spp., and Enterobacter spp. were also isolated from the hands of meat sellers (Table 1). Proteus spp. have proved to be a public health hazard and may cause infections of the urinary tract and diarrhea [34]. Food handlers may contaminate their hands with bacteria from either their own stool or during handling of the meat by the food they handle [35]. Neither stool nor food samples yielded Salmonella or Shigella isolates.

In conclusion, our findings clearly demonstrate that different Enterobacteriaceae species are common in retail meat. Insufficient awareness about foodborne zoonoses could 
TABLE 3: Identification scores for bacteria isolates obtained by Biotyper software (Bruker Daltonik GmbH) for MALDI-TOF MS results. An identification (ID) score $>2.30$ is regarded as a highly probable species identification; scores 2.0-2.29 indicate secure genus and probable species identification; scores 1.70-1.99 allow probable genus identification and lower scores provide no reliable results.

\begin{tabular}{|c|c|c|c|c|}
\hline Bacterial species & $\begin{array}{c}\text { Number } \\
\text { of } \\
\text { strains }\end{array}$ & $\begin{array}{c}\text { ID score } \\
1.70- \\
1.99\end{array}$ & $\begin{array}{l}\text { ID score } \\
2.0-2.29\end{array}$ & $\begin{array}{c}\text { ID score } \\
>2.30\end{array}$ \\
\hline Citrobacter amalonaticus & 1 & & 1 & \\
\hline Citrobacter braakii & 7 & & & 7 \\
\hline Citrobacter freundii & 8 & & 1 & 7 \\
\hline Citrobacter koseri & 3 & & & 3 \\
\hline Citrobacter youngae & 3 & & 1 & 2 \\
\hline Comamonas kerstersii & 1 & & 1 & \\
\hline Enterobacter asburiae & 2 & 1 & 1 & \\
\hline Enterobacter cloacae & 5 & & 2 & 3 \\
\hline Enterococcus faecalis & 11 & & 1 & 10 \\
\hline Enterococcus faecium & 3 & & 2 & 1 \\
\hline Enterococcus raffinosus & 1 & & 1 & \\
\hline Escherichia coli & 38 & & 11 & 27 \\
\hline Hafnia alvei & 2 & & 2 & \\
\hline Klebsiella oxytoca & 2 & & 1 & 1 \\
\hline Klebsiella pneumoniae & 17 & & 10 & 7 \\
\hline Klebsiella variicola & 2 & & 2 & \\
\hline Macrococcus caseolyticus & 4 & 1 & 3 & \\
\hline Morganella morganii & 17 & & & 17 \\
\hline Proteus mirabilis & 40 & & 4 & 36 \\
\hline Proteus penneri & 6 & & 2 & 4 \\
\hline Proteus vulgaris & 45 & & 9 & 36 \\
\hline Providencia rettgeri & 1 & & & 1 \\
\hline Providencia stuartii & 1 & & & 1 \\
\hline Pseudomonas putida & 1 & & 1 & \\
\hline Pseudomonas aeruginosa & 5 & & & 5 \\
\hline Raoultella ornithinolytica & 6 & 1 & & 5 \\
\hline Serratia liquefaciens & 1 & & & 1 \\
\hline Staphylococcus aureus & 4 & 2 & 1 & 1 \\
\hline Viridibacillus & 1 & 1 & & \\
\hline Unidentified bacteria & 4 & & & \\
\hline Total & 242 & 6 & 57 & 175 \\
\hline
\end{tabular}

endanger both retail sellers and consumers. Education of the traditional meat retailer's community in Egypt in terms of the importance of hygienic and sanitary precautions would be an important step towards safer food.

\section{Conflict of Interests}

The authors declare that they have no conflict of interests.

\section{Acknowledgments}

The authors thank Mrs. P. Methner for her excellent technical assistance. The authors would like to thank the Egyptian
Ministry of High Education and Cultural Affairs and the Missions Sector for providing a postdoctoral scholarship at FLI, Jena, Germany, to M. Gwida.

\section{References}

[1] L. Busani, G. Scavia, I. Luzzi, and A. Caprioli, "Laboratory surveillance for prevention and control of foodborne zoonoses," Annali dell'Istituto Superiore di Sanità, vol. 42, pp. 401-404, 2006.

[2] A. A. Gajadhar and R. J. Allen, "Factors contributing to the public health and economic importance of waterborne zoonotic parasites," Veterinary Parasitology, vol. 126, pp. 3-14, 2004.

[3] FAO/WHO, "Food safety risk analysis. A guide for national food safety authorities," Food and Nutrition Paper 87, FAO, Rome, Italy, WHO, Geneva, Switzerland, 2006.

[4] C. Zhao, B. Ge, J. de Villena et al., "Prevalence of Campylobacter spp., Escherichia coli, and Salmonella serovars in retail chicken, turkey, pork, and beef from the Greater Washington, D.C., area," Applied and Environmental Microbiology, vol. 67, no. 12, pp. 5431-5436, 2001

[5] D. L. Paterson, "Resistance in Gram-negative bacteria: Enterobacteriaceae," The American Journal of Medicine, vol. 119, no. 6, supplement 1, pp. S20-S28, 2006.

[6] K. C. Carroll and M. P. Weinstein, "Manual and automated systems for detection and identification of microorganisms," in Manual of Clinical Microbiology, P. R. Murray, E. J. Baron, J. H. Jorgensen, M. L. Landry, and M. A. Pfaller, Eds., pp. 192-217, ASM, Washington, DC, USA, 9th edition, 2007.

[7] I. Abubakar, L. Irvine, C. F. Aldus et al., "A systematic review of the clinical, public health and cost-effectiveness of rapid diagnostic tests for the detection and identification of bacterial intestinal pathogens in faeces and food," Health Technology Assessment, vol. 11, no. 36, pp. 1-216, 2007.

[8] A. Bizzini and G. Greub, "Matrix-assisted laser desorption ionization time-of-flight mass spectrometry, a revolution in clinical microbial identification," Clinical Microbiology and Infection, vol. 16, no. 11, pp. 1614-1619, 2010.

[9] K. Sogawa, M. Watanabe, K. Sato et al., "Use of the MALDI BioTyper system with MALDI-TOF mass spectrometry for rapid identification of microorganisms," Analytical and Bioanalytical Chemistry, vol. 400, no. 7, pp. 1905-1911, 2011.

[10] A. Croxatto, G. Prod'hom, and G. Greub, "Applications of MALDI-TOF mass spectrometry in clinical diagnostic microbiology," FEMS Microbiology Reviews, vol. 36, pp. 380-407, 2012.

[11] APHA, Compendium of Methods for the Microbiological Examination of Foods, American Public Health Association, Washington, DC, USA, 3rd edition, 1992.

[12] A. Karger, M. Ziller, B. Bettin, B. Mintel, S. Schares, and L. Geue, "Determination of serotypes of Shiga toxin-producing Escherichia coli isolates by intact cell matrix-assisted laser desorption ionization-time of flight mass spectrometry," Applied and Environmental Microbiology, vol. 77, no. 3, pp. 896-905, 2011.

[13] P. Kuhnert, S. E. Capaul, J. Nicolet, and J. Frey, "Phylogenetic positions of Clostridium chauvoei and Clostridium septicum based on 16S rRNA gene sequences," International Journal of Systematic Bacteriology, vol. 46, no. 4, pp. 1174-1176, 1996.

[14] M. F. Anjum, M. Mafura, P. Slickers et al., "Pathotyping Escherichia coli by using miniaturised DNA microarrays," Applied and Environmental Microbiology, vol. 73, pp. 5692-5697, 2007. 
[15] M. Batchelor, K. L. Hopkins, E. Liebana et al., "Development of a miniaturized microarray-based assay for the rapid identification of antimicrobial resistance genes in Gram-negative bacteria," International Journal of Antimicrobial Agents, vol. 31, pp. 440-451, 2008.

[16] K. Ballmer, B. M. Korczak, P. Kuhnert, P. Slickers, R. Ehricht, and H. Hächler, "Fast DNA serotyping of Escherichia coli by use of an oligonucleotide microarray," Journal of Clinical Microbiology, vol. 45, no. 2, pp. 370-379, 2007.

[17] S. Monecke and R. Ehricht, "Rapid genotyping of methicillinresistant Staphylococcus aureus (MRSA) isolates using miniaturised oligonucleotide arrays," Clinical Microbiology and Infection, vol. 11, no. 10, pp. 825-833, 2005.

[18] L. Geue, S. Schares, B. Mintel, F. J. Conraths, E. Müller, and R. Ehricht, "Rapid microarray-based genotyping of enterohemorrhagic Escherichia coli serotype O156:H25/H-/Hnt isolates from cattle and clonal relationship analysis," Applied and Environmental Microbiology, vol. 76, pp. 5510-5519, 2010.

[19] M. A. M. Ammar, Spoilage and pathogenic microorganisms in traditional meat products in Assuit [Ph.D. thesis], Assiut University, Assiut, Egypt, 2005.

[20] M. F. Al-Mutairi, "The incidence of Enterobacteriaceae causing food poisoning in some meat products," Advanced Journal of Food Science and Technology, vol. 3, pp. 116-121, 2011.

[21] A. Von Holy, W. H. Holzapfel, and G. A. Dykes, "Bacterial populations associated with Vienna sausage packaging," Food Microbiology, vol. 9, no. 1, pp. 45-53, 1992.

[22] C. O. Gill, "Sources of bacterial contamination at slaughtering plants," in Improving the Safety of Fresh Meat, J. N. Sofos, Ed., pp. 231-243, CRC/Woodhead Publishing, Cambridge,UK, 2005.

[23] I. S. Gibbons, A. Adesiyun, N. Seepersadsingh, and S. Rahaman, "Investigation for possible source(s) of contamination of readyto-eat meat products with Listeria spp. and other pathogens in a meat processing plant in Trinidad," Food Microbiology, vol. 23, no. 4, pp. 359-366, 2006.

[24] H. S. Hussein, "Prevalence and pathogenicity of Shiga toxinproducing Escherichia coli in beef cattle and their products," Journal of Animal Science, vol. 85, pp. E63-E72, 2007.

[25] G. J. E. Nychas, P. N. Skandamis, C. C. Tassou, and K. P. Koutsoumanis, "Meat spoilage during distribution," Meat Science, vol. 78, pp. 77-89, 2008.

[26] H. R. Tavakol and M. Riazipour, "Microbial quality of cooked meat foods in Tehran University's restaurants," Pakistan Journal of Medical Sciences, vol. 24, no. 4, pp. 595-599, 2008.

[27] F. A. Elnawawi, O. A. Attala, and S. Saleh, "Enteropathogens of public health importance in imported frozen meat and chicken," International Journal of Microbiology Research, vol. 3, pp. 59-63, 2012.

[28] P. S. Mead, L. Slutsker, V. Dietz et al., "Food-related illness and death in the United States," Emerging Infectious Diseases, vol. 5, pp. 607-625, 1999.

[29] C. M. Schroeder, D. G. White, and J. Meng, "Retail meat and poultry as a reservoir of antimicrobial-resistant Escherichia coli," Food Microbiology, vol. 21, pp. 249-255, 2004.

[30] T. S. El-Khateib, Sanitary condition of sausage in Assiut [M.S. thesis], Assiut University, Assiut, Egypt, 1982.

[31] F. Scheutz, L. D. Teel, L. Beutin et al., "Multicenter evaluation of a sequence-based protocol for subtyping Shiga toxins and standardizing Stx nomenclature," Journal of Clinical Microbiology, vol. 50, pp. 2951-2963, 2012.
[32] T. Wong, R. J. Whyte, A. J. Cornelius, and J. A. Hudson, "Enumeration of Campylobacter and Salmonella on chicken packs," British Food Journal, vol. 106, no. 9, pp. 651-662, 2004.

[33] R. Stephan, S. Ragettli, and F. Untermann, "Prevalence and characteristics of verotoxin-producing Escherichia coli (VTEC) in stool samples from asymptomatic human carriers working in the meat processing industry in Switzerland," Journal of Applied Microbiology, vol. 88, no. 2, pp. 335-341, 2000.

[34] M. J. Lewis, "Escherichia, Shigella," in Medical Microbiology: A Guide to Microbial Infections: Pathogenicity, Immunity, Laboratory Diagnosis and Control, D. Greenwood, R. Slack, and J. Peutherer, Eds., Addison Wesley Longman, Hong Kong, China, 15th edition, 1998.

[35] P. N. Acha and B. Pzyfers, Zoonoses and Communicable Diseases Common to Man and Animals, Washington, DC, USA, 2nd edition, 1991. 

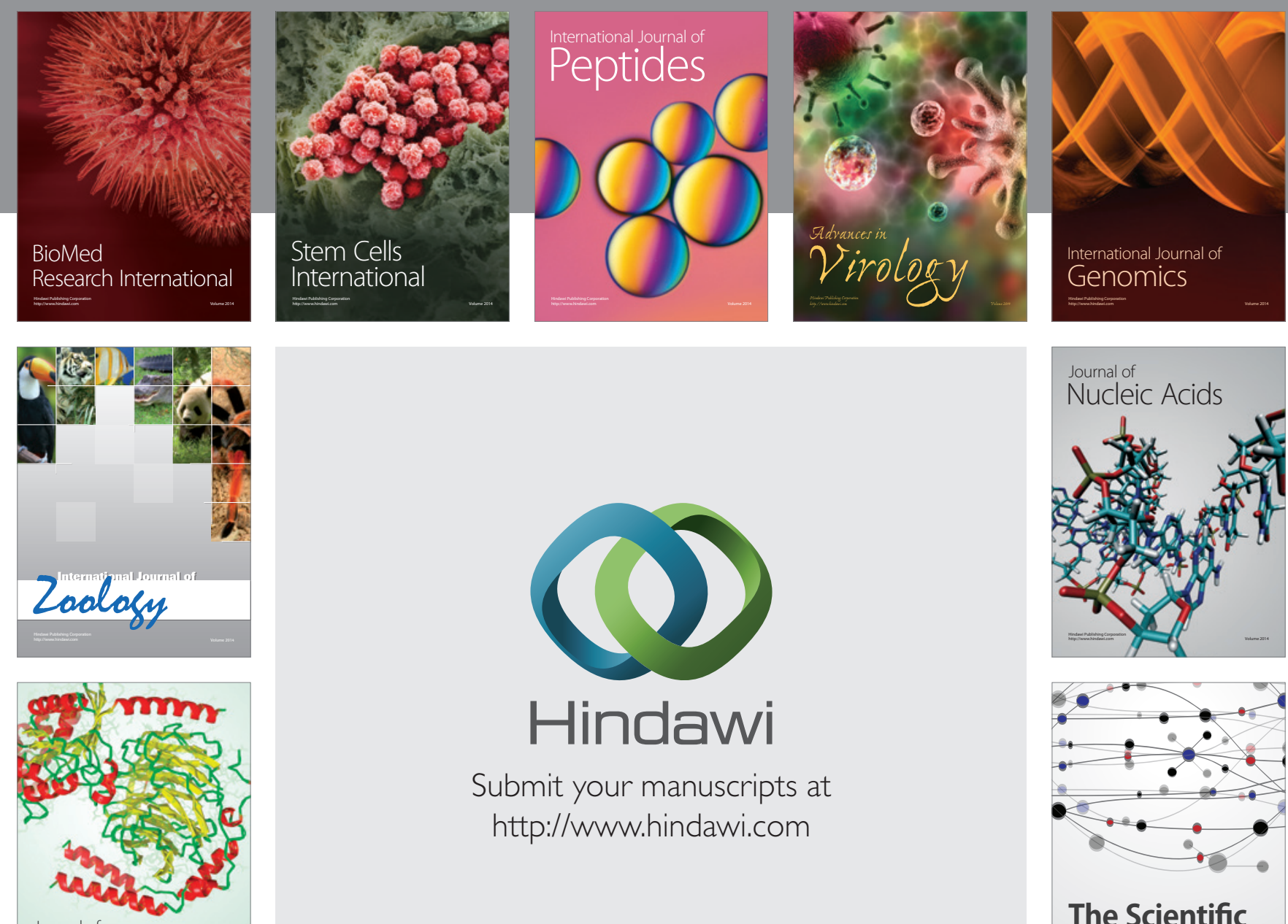

Submit your manuscripts at

http://www.hindawi.com

Journal of
Signal Transduction
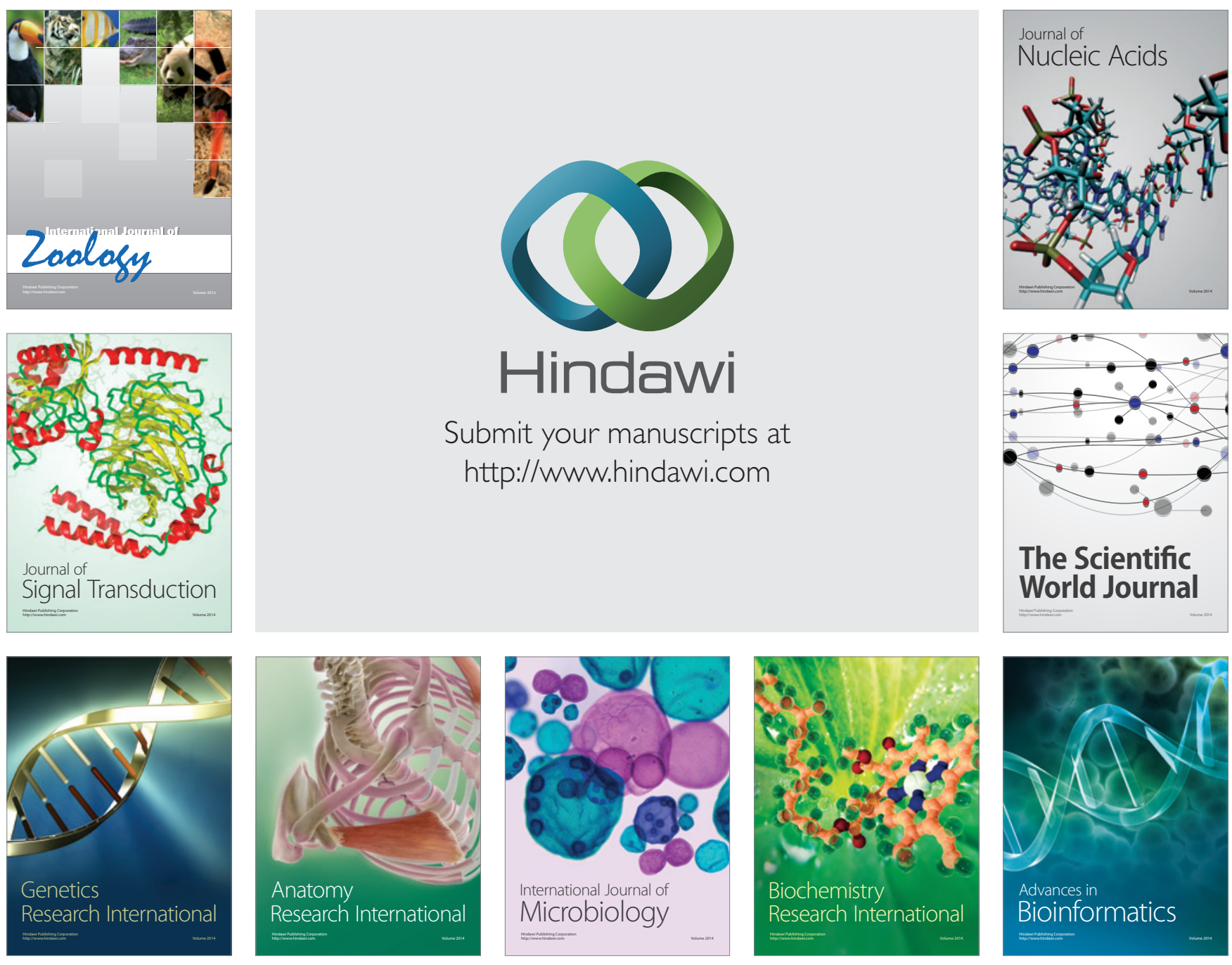

The Scientific World Journal
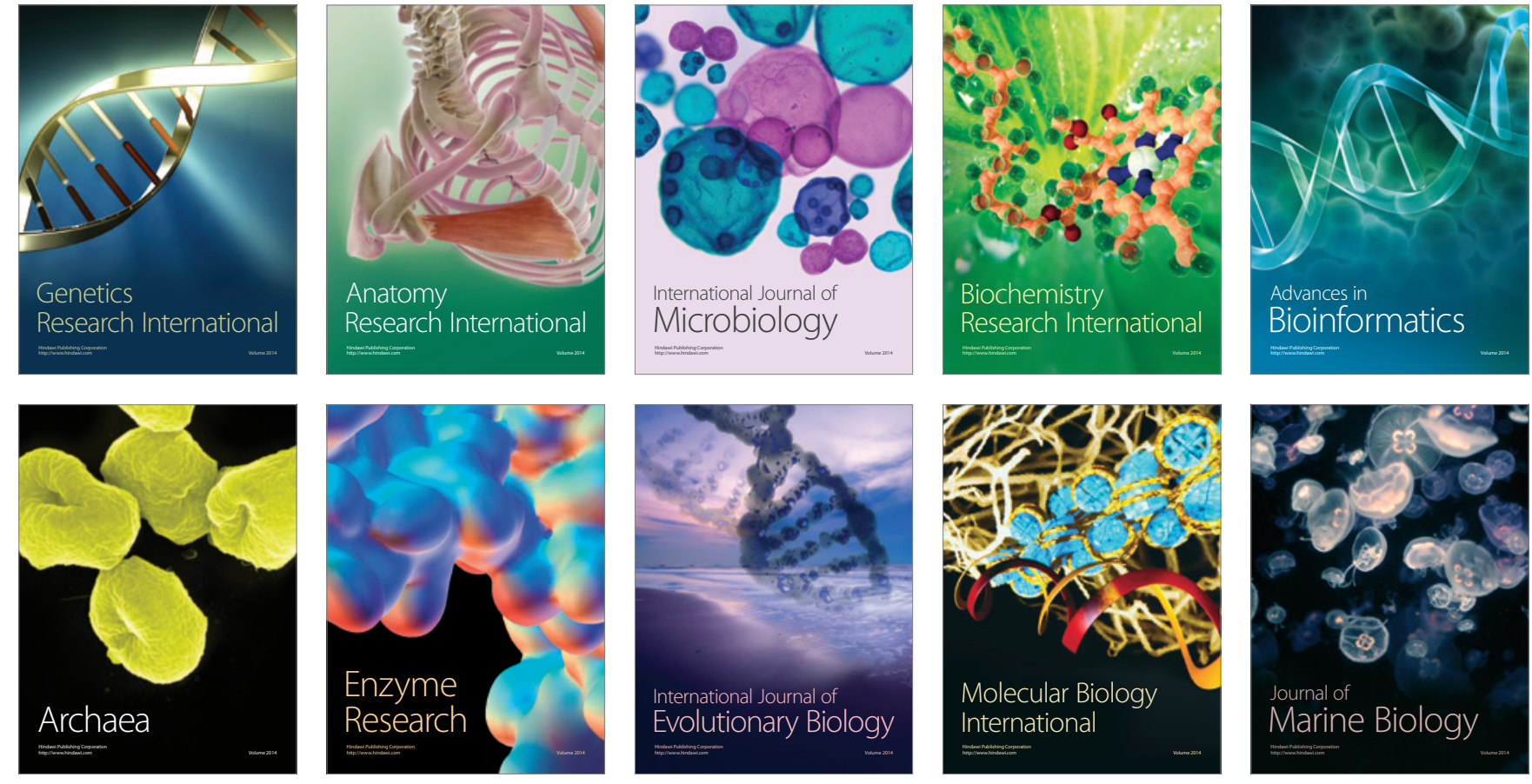